\title{
School screening for scoliosis, the Greek experience
}

\author{
Panayotis K Soucacos \\ From 7th International Conference on Conservative Management of Spinal Deformities \\ Montreal, Canada. 20-22 May 2010
}

\begin{abstract}
A two year prospective study was done to assess the prevalence and distribution of various parameters associated with scoliosis in schoolchildren in northwestern and central Greece. A total of 82.901 children (41.939 boys and 40.962 girls) who were nine to fourteen years old were screened for scoliosis. The forward bending test was performed and the children in whom scoliosis was suspected were re-evaluated. Posteroanterior and lateral radiographs were made to the children with positive findings at the time of the re-evaluation. The prevalence of scoliosis (curve of 10 degrees or more) was $1.7 \%$ and most of the curves $1.5 \%$ were small (10 to 19 degrees). Thoracolumbar curves were the most common type, followed by lumbar curves, thoracic curves and double curves. Most of these curves were to the left. The cost of the screening process was negligible (estimated at thirty cents per child); however, the decreased number of operative procedures performed, the identification of a large number of previously undiagnosed curves (11 of which were treated operatively and 170 of which were treated with brace), and the identification of children who were at high risk for progression were considered important benefits of the school-screening program.
\end{abstract}

Submit your next manuscript to BioMed Central and take full advantage of:

- Convenient online submission

- Thorough peer review

- No space constraints or color figure charges

- Immediate publication on acceptance

- Inclusion in PubMed, CAS, Scopus and Google Scholar

- Research which is freely available for redistribution

Submit your manuscript at www.biomedcentral.com/submit
C Biomed Central 